\title{
Clinical, imaginological and pathological aspects of umbilical panvasculitis in calves: case report
}

\author{
Aspectos imaginológicos e clínico-patológicos de \\ panvasculite umbilical em bezerro: relato de caso
}

\author{
Amabile Arruda de Souza e Silva ${ }^{*}$ (D), Walter Henrique Cruz Pequeno ${ }^{(\mathbb{D})}$, Raoane Silva Siqueira ${ }^{2}$ (D), \\ Karla Campos Malta ${ }^{1}$, Vanessa Martins Fayad Milken ${ }^{3} \mathbb{B}^{0}$, Suzana Aparecida Costa de Araújo ${ }^{1}$, \\ Ricardo Barbosa de Lucena (1), Sara Vilar Dantas Simões ${ }^{1}$ (D)
}

\begin{abstract}
The diagnosis of umbilical infections in neonates can be obtained from clinical signs, but the intracavitary involvement of structures and associated complications can be underestimated, compromising the establishment of adequate therapeutic approaches or prognosis. This case report presents the clinical, imaging, pathological and microbiological aspects of an umbilical infection in calves. Physical examination of the animal identified apathy, low body score, increased volume in the umbilical region and joints. The abdominal palpation identified firm structures in topography of the arteries and umbilical vein. Imaging examinations of the abdomen and joints were performed. Multiple, hyperechogenic focal structures have been identified in the liver, as well as cylindrical and firm structures in topography of the arteries and umbilical vein. In the joints, osteolytic changes, periosteal reactions, subchondral sclerosis and formation of osteophytes were seen. Umbilical panvasculitis triggered arthritis and an infectious process in the liver, the case being assessed as having an unfavorable prognosis and the animal being referred for euthanasia. At necropsy, multifocal abscesses were observed in the pleura, ribs, omentum, spleen and liver. There was granulomatous exudate in the urinary vesicle. The affected joints presented thickening of the joint capsule with the presence of exudate. In the microbiological analysis of liver fragments, urinary vesicle content and joint exudate, Proteus mirabilis with resistance to antimicrobials was identified. Imaging studies collaborated with the establishment of the prognosis and conduct adopted, and must, whenever possible, be included in the clinical examination. In case of death, necropsy allows a correct association of clinical signs and imaging findings.
\end{abstract}

KEYWORDS: neonates; conditions, ultrasound study; ruminants;

RESUMO: O diagnóstico das infecçôes umbilicais em neonatos pode ser obtido a partir do exame clínico, porém o comprometimento intracavitário das estruturas e as complicaçóes associadas podem ser subestimados, comprometendo o estabelecimento de condutas terapêuticas ou prognósticos adequados. Apresenta-se nesse trabalho os aspectos clínicos, imaginológicos e patológicos de uma infecção umbilical em bezerro. No exame físico do animal identificou-se apatia, baixo escore corporal, aumento de volume na região umbilical e articulaçóes e, em palpação abdominal, estruturas firmes em topografia das artérias e veia umbilical. $\mathrm{Na}$ avaliação ultrassonográfica abdominal identificou-se estruturas focais múltiplas, hiperecogênicas no fígado e estrutura bem definida, com parede hipoecoica e lúmen hiperecoico, estendendo-se de lobo hepático até porção cranial do anel umbilical. $\mathrm{Na}$ radiografia das articulações foram vistas alteraçôes osteolíticas, reação periosteal, esclerose e formação de osteófitos, além do aumento de volume e radiopacidade de tecido moles adjacentes com presença de áreas radiolucentes, indicando presença gasosa local. Os sinais clínicos e os achados imaginológicos demonstraram a ocorrência de panvasculite umbilical que desencadeou um quadro de poliartrite séptica e processos infecciosos em diversos órgáos. O estudo imaginológico permitiu identificar onfaloflebite, grave acometimento de parênquima hepático e artrites sépticas, sendo o caso avaliado como tendo um prognóstico desfavorável e o animal eutanasiado. $\mathrm{O}$ tratamento conservador com antibioticoterapia prolongada e/ ou a retirada ou marsupialização dos remanescentes umbilicais infectados podem ser utilizados em casos de onfaloflebites ou onfaloarterites. No entanto, esse procedimento não foi adotado devido ao comprometimento hepático e aos achados radiográficos que demonstraram ocorrência de osteoartrite séptica.

PALAVRAS-CHAVE: neonatos; condiçóes, estudo de ultrassom; ruminantes 


\section{INTRODUCTION}

The umbilical cord is covered by the amniotic membrane and consists of two arteries, the umbilical vein and the uracus. It is through these structures, and their connection with the placenta, that the fetus is able to ensure its demands for oxygen, water, nutrients and eliminate the waste of metabolism in the maternal blood. The umbilical arteries are located laterally in the bladder and carry oxygen-poor blood from the fetus. After birth, these arteries become the lateral ligaments of the urinary bladder. The urracus (allantoic duct) is a structure that presents itself as a continuation of the fetal urinary vesicle taking waste to the allantoic sac, soon after birth atrophies and disappears in healthy calves. The umbilical vein goes cranially to the liver of the fetus, carrying blood rich in oxygen and nutrients (BAIRD, 2016).

At the time of birth, the umbilical cord ruptures, the amniotic membrane coils, and gradually the arteries, vein and uracus close, but some structures still remain temporarily exposed and can be a "gateway" for pathogens (SEINO et al., 2016). Infection of the umbilicus and associated structures is a frequent problem in livestock, particularly in calves, and can lead to extra-cavitary (omphalitis) or intracavitary infectious processes. The intracavitary processes can reach the allantoic duct, umbilical arteries and veins and gain specific names according to the structures they reach, such as omphalophlebitis, omphaloarteritis, omphalouraquitis, or the combination of these diseases (panvasculitis) (STURION et al., 2013). The progression of infections to areas beyond the navel leads to cases of bacteremia and localization of causative agents in places such as liver, urinary bladder, joints, bones, among other organs (STURION et al., 2013; HALAYEL et al., 2014).

The diagnosis of umbilical infections can be obtained from the clinical examination, during which bimanual palpation of the umbilical and abdominal region must be performed. However, in some cases the intracavitary involvement of the structures and the associated complications can be underestimated, which compromises the establishment of adequate therapeutic approaches or prognosis. In such cases, more specific diagnostic methods such as imaging tests are needed, the ultrasound examination being a non-invasive method that allows good visibility of the organs of the abdominal cavity and umbilical structures (STURION et al., 2013).

As a way of collaborating with the diagnosis and prognosis of umbilical disorders in calves, the clinical, imagological and pathological aspects of panvasculitis are presented in this case report, and some microbiological aspects are also presented.

\section{CASE REPORT}

A male, two-month-old calf, $33 \mathrm{~kg}$, was admitted in the Veterinary Hospital of Federal University of Paraiba, with a primary complaint of difficulties in locomotion and swelling in the joints of the right and left hind limbs. The general physical examination revealed that the calf was apathetic, reluctant to move, with arched back, mild dehydration (7\%), hyper-colored oculopalpebral mucous membranes, engorged episclerotic vessels, low body score and increased volume in the umbilical region and femur joints -tibio-patellar of the right posterior limb and tibio-tarsal of the left posterior limb. In the specific examination of the umbilical region and joints, it was possible to identify that the umbilicus was hot, sensitive, swollen and with the presence of purulent secretion.secretion in lesion in themedial region of the affected joint of the left posterior limb (Figure 1 - A and B). In deep bimanual abdominal palpation, cylindrical and firm structures were verified in topography of the arteries and umbilical vein, indicating the need for of the ultrasound examination. Radiographic examinations of enlarged
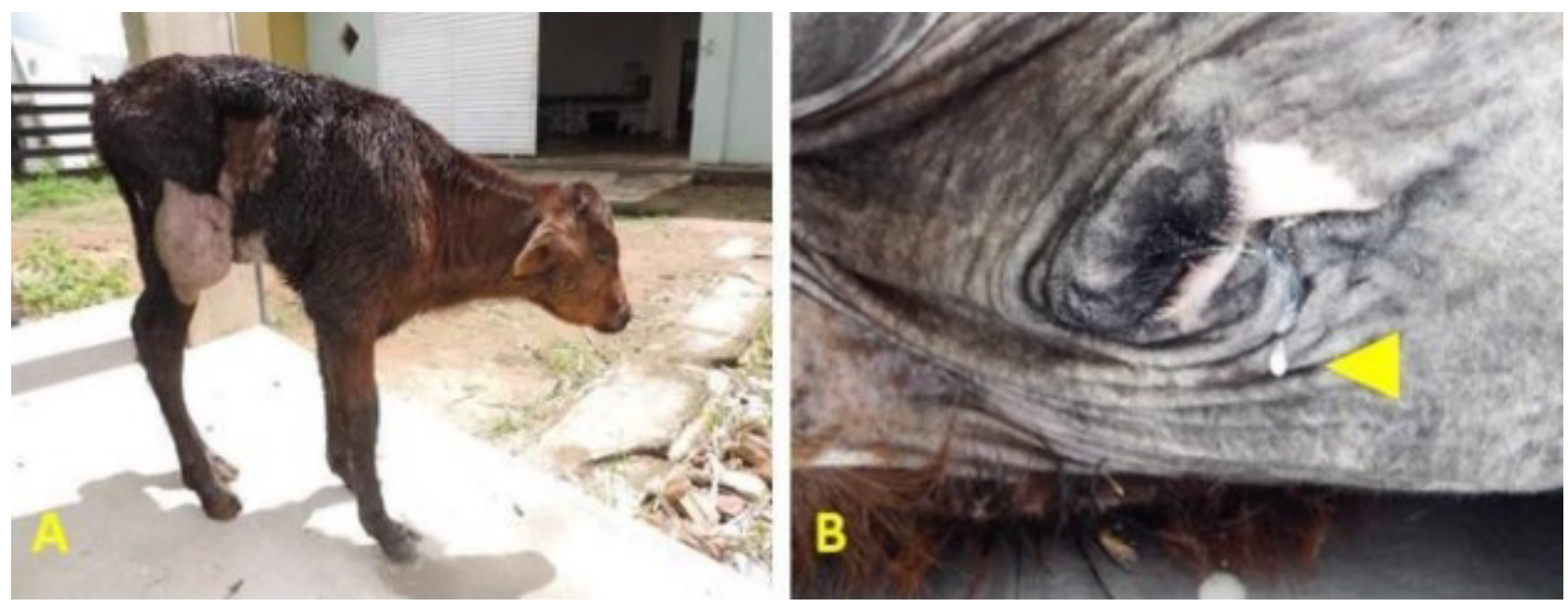

Source: author's collection.

Figure 1. Clinical signs identified in calves with umbilical panvasculitis. A - Low body score, back arch and increased volume in the femorofibio-patellar joint of the right posterior limb. B -- umbilicus with enlarged volume and presence of purulent secretion (triangular arrow).umbilicus with swelling and presence of purulent secretion (triangular arrow). 
joints were also requested. The animal was hospitalized and, based on the clinical signs presented, treatment with flunixin meglumine started at a dose of $1.1 \mathrm{mg} / \mathrm{kg}$ SID intravenously and gentamicin at a dose of $4 \mathrm{mg} / \mathrm{kg}$ BID intramuscularly.

The ultrasonographic evaluation of the intracavitary structures and the umbilical ring were performed using the logiq E (GE) ultrasound, following the methods of positioning, scanning and plans by Sturion et al. (2013), where the animal was positioned in the right lateral decubitus position, with the umbilical vein being evaluated after scanning the liver, in a longitudinal plane, going in the caudal direction to the umbilical ring. The umbilical arteries and allantoic duct were also evaluated in the longitudinal plane, first at the height of the urinary vesicle, following cranially to the umbilical ring, which was evaluated in the transverse plane.

In the liver, it was seen the presence of multiple rounded structures, with hyperechoic walls, irregular margins and heterogeneous echotexture of varying sizes, with intense concentration in the left lateral and medial lobes. Within the abdominal cavity, adjacent to the left hepatic region, it was possible to identify a well-defined structure with a hypoechoic wall with hyperechoic points and hyperechoic lumen, extending from its entry into the hepatic lobe to the cranial portion of the umbilical ring, with a diameter of $3.87 \mathrm{~cm}$ and a wall thickness of $0.9 \mathrm{~cm}$, suggesting it to be the umbilical vein. None of the cord components were seen at the height of the urinary bladder, but in a region caudal to the umbilical ring, a well-defined structure was observed, with dense and heterogeneous echogenic content, hypoechoic wall, with a diameter of $1.30 \mathrm{~cm}$, and it is not possible to define whether they were umbilical arteries or allantoic duct, as longitudinal images of arteries and urraco were not well defined. None of the cord components were seen in an umbilical ring (Figure 2 - A, B, C and D).

The radiographs of the joints were performed with the CARESTREAM CR vita flex computerized radiography device. The left tarsus showed radiolucent areas with sclerotic margins in the metaphysis and metatarsal epiphysis regions,
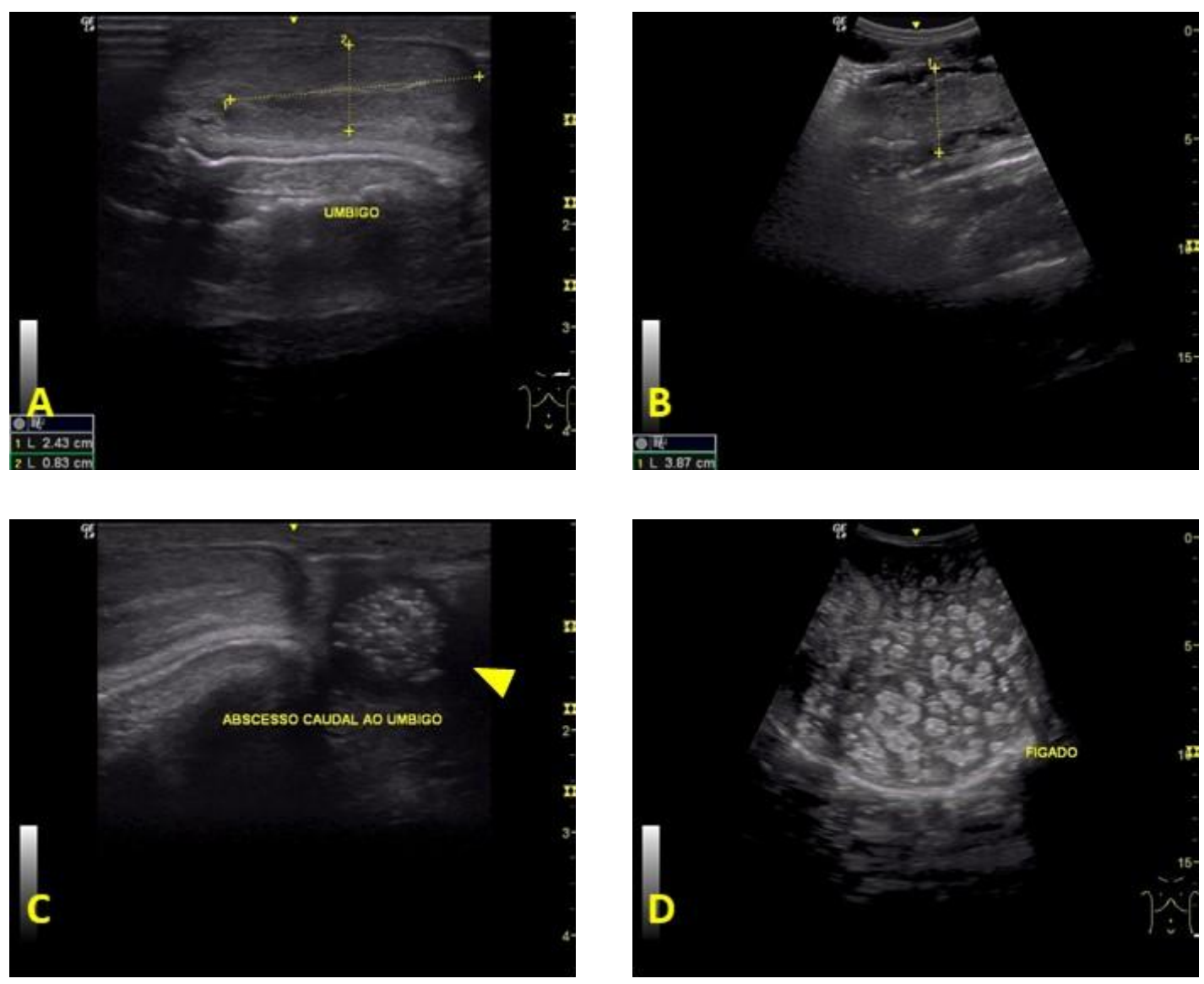

Source: author's collection

Figure 2. Ultrasonographic aspects of intra-abdominal umbilical structures and calf liver affected by panvasculitis. A - Cross section of the umbilical ring showing a single hyperechoic line referring to the topography of arteries and umbilical veins. B - Longitudinal section of the umbilical vein at an intermediate point between the liver and the umbilical ring, hyperechoic lumen and thickened, hypoechoic vascular wall with hyperechoic points. C - Cross section of the structure with a hypoechoic wall, heterogeneous, caudal content and close to the umbilical ring (triangular arrow). D - Hepatic sonogram showing the presence of multiple rounded structures, with hyperechoic walls, irregular margins and heterogeneous echotexture. [Convex transducer 4.0 - 5.5 MHz; linear 10.0 MHz]. 
centroquarto and tarsals II and III, irregularities of the subchondral bone of the tarsal and metatarsal bones, increase in volume and radiopacity of soft tissue with radiolucent areas, indicating the presence of gas, osteophytes and periosteal reaction in the proximal dorsal margin of the metatarsus. The right femur-tibio-patellar joint showed radiolucent areas with sclerotic margins in the lateral tibial condyle, swelling and soft tissue radiopacity with radiolucent areas, suggestive of the presence of gas (Figure 3 - A and B).

Due to liver and umbilical vein injuries, in addition to the presence of arthritis and unsatisfactory response to the treatment instituted, the animal was euthanized. The procedure used was general anesthesia with the use of xylazine at a dose of $0.05 \mathrm{mg} / \mathrm{kg}$ and ketamine at a dose of $2 \mathrm{mg} / \mathrm{kg}$ both intravenously, followed by intravenous potassium chloride at a dose of $100 \mathrm{mg} / \mathrm{kg}$. At necropsy, multifocal abscesses were observed in the pleura, ribs, omentum, spleen and liver. Liver abscesses were concentrated in the left lateral and medial lobes, with sizes varying between 0.2 and $1.2 \mathrm{~cm}$. The umbilical vein was full of thick purulent content, also seen in the region of adherence of umbilical arteries and allantoic duct. The right and left umbilical arteries contained thrombi and necrosis points distributed in a multifocal manner in their extension and were joined to the allantoic duct, forming a single structure. In the urinary vesicle there was the presence of granulomatous exudate and hyperemic areas in the mucosa. Areas
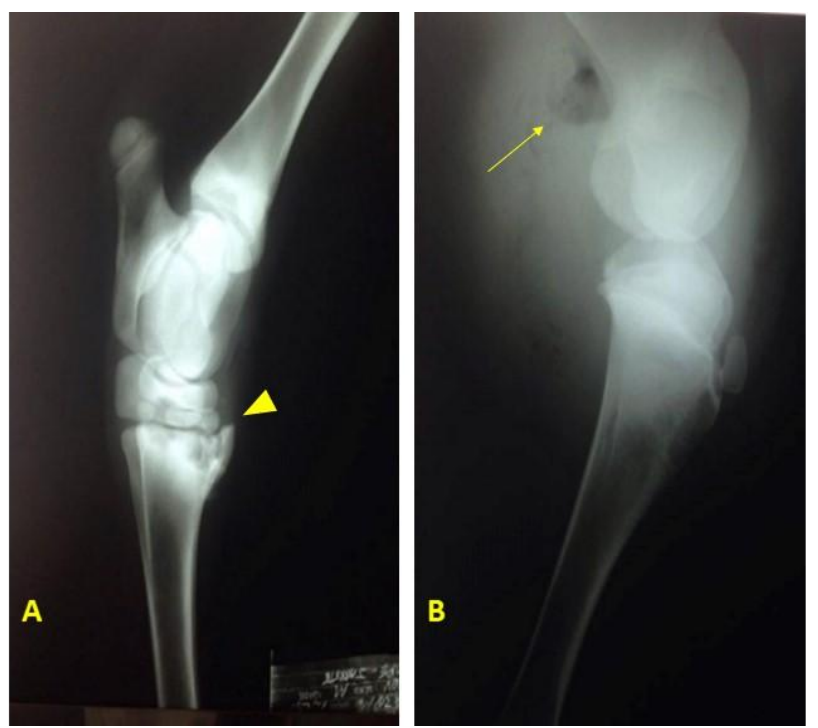

Source: author's collection.

Figure 3. Radiographic aspects of the left tibio-tarsal and right femur-tibio-patellar joints of a calf affected by umbilical panvasculitis. The lateral-medial projection. Presence of radiolucent area with sclerotic margins in the metaphysis and metatarsal epiphysis regions, irregularities in the subchondral bone, formation of osteophytes and periosteum reaction (triangular arrow). B - Lateral-medial projection. Presence of increased volume and radiopacity of the adjacent tissue and joint region, in addition to the region with the presence of gas (thin arrow). of white-colored, focal wedge-shaped infarction were seen in the right kidney. The affected joints presented external and internal thickening of the joint capsule with the presence of exudate (Figure 4 - A, B, C and D).

Liver fragments, urinary vesicle content and joint exudate were collected for microbiological analysis. Biochemical and Gram tests were performed, resulting in cocobacillus bacteria, Gram negative, positive catalase and negative oxidase for all liver and urine colonies. The commercial Bac Tray I and II ${ }^{\circ}$ test from the BHI Agar sample, identified a result compatible with Proteus mirabilis. The Kirby and Bauer method for testing sensitivity to antimicrobials in vitro was used to determine the resistance of the isolate against eight antimicrobial principles used in the clinical routine (Table 1).

\section{DISCUSSION}

The clinical signs identified in the animal demonstrated the occurrence of an umbilical condition with compromised intra and extra-cavitary joints and structures, however the establishment of the prognosis of the case was only established more safely after performing the imaging tests, which allowed to identify the extensive impairment of abdominal organs and joints. In the literature, studies such as those carried out by Yanmaz et al. (2017), where the authors presented a system of clinical scores to assist in the establishment of conducts, especially in cases where ultrasound exams are not available, however if the scores presented were used in the animal in this report, we would not obtain the one classified as unfavorable.

The clinical signs and the imaging findings suggested umbilical panvasculitis, a process that caused bacteremia and organ involvement, as identified in the autopsy findings. The compromise of intra and extra-abdominal umbilical structures demonstrated that the origin of the infectious process had the umbilical cord as the "gateway". Miranda et al. (2016), point out that before the cord dehydrates and mummification of the umbilical stump occurs, the passage to the neonate's bloodstream is still open, and in case of improper treatment of the umbilical stump, the navel is exposed to environmental contamination, which is the largest and most important gateway for microorganisms.

The ultrasound visualization of the cranial structure to the navel extending to the liver, with hyperechoic contentand easily identifiable walls, proved the clinical suspicion of omphalophlebitis, in addition, the imaging study allowed to identify the severe involvement of the liver parenchyma. The hypoechogenicity and increased thickness identified in the umbilical vein wall are consistent with the inflammatory process, and the hyperechogenicity of the lumen may be associated with the time of evolution of the process and the large amount of cellularity of the purulent content, whose presence was proven at the time of necropsy. (KACHARE et al., 2014). The fusion of umbilical arteries and allantoic duct identified at necropsy was probably due to adhesions by exudate and justifies the ultrasound finding of a single caudal structure to the umbilical ring. 
The presence of intra-articular radiolucent areas that represent gas is a potential finding of septic arthritis (BEGGS, 2013). The absence of cutaneous lesions in the region of the femur-tibio-patellar joint, associated with the other findings of the animal, suggest that the joint infection occurred through hematogen, which according to a study carried out with 64 calves is the most common etiology of septic arthritis in calves (CONSTANT et al., 2018).

The agent Proteus mirabilis, isolated enterobacteria in liver abscesses and urine is, along with skin eaters, one of the main causes of omphalitis in calves (ÁLVAREZ; PEÑATE; BERNATE, 2013), and in this case demonstrated resistance to several antibacterial principles, including the one that started the treatment. It was not possible to wait for the result of the antibiogram to institute an antimicrobial treatment of proven efficacy due to the long time to obtain the results in addition to the clinical condition that the animal was at the time of the initial care.

Conservative treatment with prolonged broad-spectrum antibiotic therapy can be an effective alternative in cases of
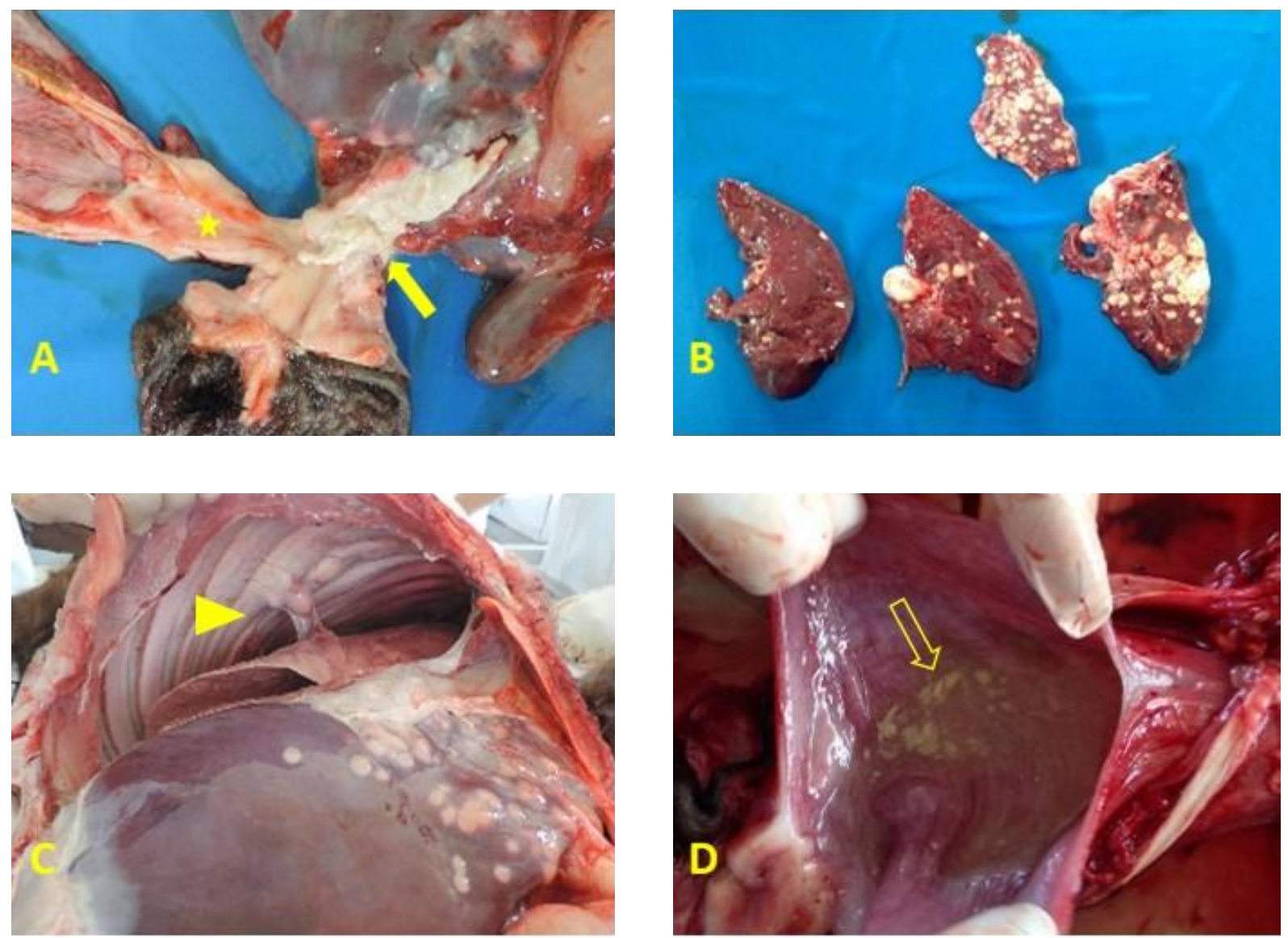

Source: author's collection.

Figure 4. Necropsy findings of the intra-abdominal umbilical structures and internal organs of a calf affected by panvasculitis. A Intra-abdominal umbilical structures, umbilical vein (filled arrow), umbilical arteries attached to the allantoic duct (star) with dense purulent secretion in its extensions. B - Liver, cross sections with multiple abscesses. C - Pleura and ribs with multifocal abscesses and adhesions. D - Urinary vesicle with granulomatous exudate (empty arrow).

Table 1. Antimicrobial sensitivity test for Proteus mirabilis isolated from liver fragments collected at necropsy of calf with septicemic panvasculitis.

\begin{tabular}{c|c|c|c|c|c|c|c|c|c|c|c|c|c|c|c|}
\multicolumn{10}{c|}{ Antimicrobial Sensitivity Test } \\
\multicolumn{10}{c|}{ AMP } & \multicolumn{10}{c|}{ AMC } & \multicolumn{2}{c|}{ CIP } & \multicolumn{2}{c|}{ AMI } & \multicolumn{2}{c|}{ CFL } & \multicolumn{2}{c|}{ GEN } & \multicolumn{2}{c|}{ SUT } & TET \\
\hline $\mathrm{R}$ & $\mathrm{S}$ & $\mathrm{R}$ & $\mathrm{S}$ & $\mathrm{R}$ & $\mathrm{S}$ & $\mathrm{R}$ & $\mathrm{S}$ & $\mathrm{R}$ & $\mathrm{S}$ & $\mathrm{R}$ & $\mathrm{S}$ & $\mathrm{R}$ & $\mathrm{S}$ & $\mathrm{R}$ & $\mathrm{S}$ \\
\hline+ & - & + & - & - & + & - & + & + & - & + & - & + & - & + & - \\
\hline
\end{tabular}

$\mathrm{R}=$ resistant; $\mathrm{S}=$ susceptible; $\mathrm{AMP}=$ Ampicillin; $\mathrm{AMC}=$ Amoxicillin + clavulanate; $\mathrm{CIP}=$ Ciprofloxacin; $\mathrm{AMI}=$ Amikacin; $\mathrm{CFL}=\mathrm{Ceflotin} ; \mathrm{GEN}=$ Gentamycin; SUT = Sulfazotrim; ETT = Tetracycline. 
omphalophlebitis or omphaloarteritis, but if medical therapy is ineffective, the infected umbilical remnants must be marsupialized or excised (NAVARRE; BAIRD; PUGH, 2012). However, this procedure was not adopted due to extensive hepatic impairment and radiographic findings that demonstrated osteoarthritis, identified after the imaging study.

\section{CONCLUSION}

Imaging studies collaborated with the establishment of the prognosis and conduct adopted in the case, and must, whenever possible, be included in the clinical examination. In case of death, it is important to perform necropsy because it allows a correct association of clinical signs and findings and imaging.

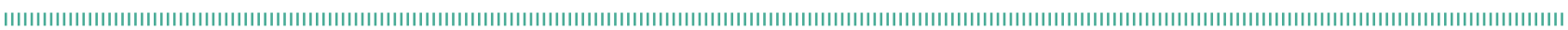
REFERENCES

Álvarez, J. A. C.; PeñAte, J. Á.; Bernate, G. A. Perfil de susceptibilidad antimicrobiana de bactérias aisladas desde onfalitis en terneros de 10 explotaciones ganaderas del departamento de Córdoba, Colombia. Veterinaria y Zootecnía, v. 7, n. 1, p. 62-70, 2013.

BAIRD, A. N. Surgery of the umbilicus and related structures. Veterinary Clinics of Food Animals, v. 32, p. 673-685, 2016.

BEGGS, I. Musculoskeletal Ultrasound. 1. ed. Philadelphia, PA: Lippincott Williams \& Wilkins, 2013. 464 p.

CONSTANT, C. et al. Clinical findings and diagnostic test results for calves with septic arthritis: 64 cases (2009-2014). Journal of American Veterinary Medical Association, v. 25, n.2, p. 995-1005, 2018.

HELAYEL, M. A. et al. Aspectos clínico-patológicos, microbiológicos e hematológicos de abscesso cerebral em bovinos - Relato de caso. Revista Brasileira de Medicina Veterinária, v. 36, n. 3, 2014.

KACHARE M. B. et al. Gas-forming liver abscess in a patient with multi-organ failure: role of imaging and management. Acta Clinica Belgica, v. 69, n. 3, p. 226-228, 2014.
MIRANDA, J. O. F. et al. Evidências para as práticas de cuidado do coto umbilical: Revisão integrativa. Revista enfermagem UFPE on line, v. 10 (Supl. 2), 2016.

NAVARRE, C. B.; PUGH, D. G.; BAIRD, A. N. Diseases of the gastrointestinal system. In: PUGH, D. G.; BAIRD, A. N. 2. ed. Sheep and Goat Medicine. Missouri, MO: Elsevier, 2012. p. 103-105.

SEINO, C. H. et al. Avaliação ultrassonográfica de componentes umbilicais inflamados em bezerros da raça Holandesa com até 30 dias de vida. Pesquisa Veterinária Brasileira, v. 36, n. 6, p. 492-502, 2016.

STURION, T. T. et al. Avaliação ultrassonográfica da involução das estruturas umbilicais extra e intracavitárias em bezerros sadios da raça Nelore concebidos naturalmente e produtos de fertilização in vitro. Pesquisa Veterinária Brasileira, v. 33, n. 8, p. 1021-1032, 2013.

Yanmaz L. E. et al. Estimation of outcome of umbilical diseases based on clinical examination: A retrospective study involving 322 calves. Israel Journal of Veterinary Medicine, v. 72, n. 2, p. 40-44, 2017. 